J. Product. \& Dev., 24(3): $433-460$ (2019)

\title{
INFLUENCE OF SOME SQUASH CULTIVARS AND GROWTH STIMULANTS ON FLOWERING, YIELD AND FRUIT QUALITY AT AUTUMN - WINTER SEASON UNDER OPEN FIELD CONDITIONS
}

\section{A. R. Salama; Wafaa, A. Fekry and H. M. Wahdan}

Plant Production Department, Faculty of Technology and Development, Zagazig University, Egypt ${ }^{*}$.

*Corresponding author: E.mail: drwafaaadel@hotmail.com

\section{ABSTRACT}

This investigation was conducted at the Experimental Farm, Fac. Tech. and Develop. (Gazala region - Zagazig), Zagazig Univ., Sharkia Governorate under open field during the two fall - winter seasons of 2015/2016 and 2016/2017, to study the effect of three cultivars of squash ( Eskandarany, Revera and Azyad) and foliar spray treatments with, yeast extract at the rate of 3 and $6 \mathrm{gl}^{-1}$, as well as potassium silicate at the rate of 2 and $4 \mathrm{gl}^{-1}$ plus control (tap water)and their interactions on flowering expression, i.e., number of male and female flowers plant ${ }^{-1}$, sex ratio and femalness percentage, yield and its components (number of fruits plant $^{-1}$, fruit fresh weight, and dry matter percentage, total fruit yield plot ${ }^{-1}$ and relative yield), as well as fruit quality, i.e., fruit physical characters (both of fruit length and diameter) and fruit chemical composition (nitrogen, phosphorus and potassium content, protein and total carbohydrates percentage). Results showed the superiority of the two tested cultivars Azyad and Revera at all studied characteristics compared with Eskandarany $c v$. Spraying with yeast extract or potassium silicate significantly increased most parameters of flowering, fruit yield and quality attributes of squash than control treatment . Moreover, spraying plants with potassium silicate at rate of $4 \mathrm{gl}^{-1}$ or yeast extract at $6 \mathrm{gl}^{-1}$ significantly surpassed compared with the other foliar treatments and control in this respect. The best results of the interaction treatments for flowering, yield and fruit parameters were recorded by the two cultivars Azyad or Revera combined with the foliar 
spray by $4 \mathrm{gl}^{-1}$ of potassium silicate or $6 \mathrm{gl}^{-1}$ of yeast extract which recorded increased in most of all the mentioned studied parameters.

Hence, each of these treatments could be recommended for enhancement flowering, yield and fruit quality of squash plants with low cost production when planted in open field at fall - winter season under the same conditions of this experiment.

Key words: Squash, cultivars, yeast extract, potassium silicate, flowering, yield, fruit quality

\section{INTRODUCTION}

Squash (Cucurbita pepo L.) is one of the most popular cucurbits vegetable crops grown in Egypt. The immature fruits are eaten as boiled, fried or stuffed. It has Various health and medicinal benefits of human (Bannayan et al., 2011). Squash fruits contain considerable amounts of carbohydrates, proteins, minerals and vitamins (Base et. al., 2000).

Squash is cultivated all over the year in Egypt, in open field during spring and summer, where in tunnels or - greenhouse in fall and winter. Global climate changes, i.e., amount of $\mathrm{CO}_{2}$, solar radiation and changes in temperature, the intensity of extreme weather have a different effects of plants at molecular function, morphological characteristics, physiology and developmental processes (Gray and Brady, 2016). In this concern, there is an urgent need to improve agricultural practices to ensure that crop production is balanced with environmental sustainability. Under climate changes the production of vegetable crops may be improved by using various novel agricultural practices, i.e., suitable new cultivars, modification of sowing date, as well as spraying growth stimulants such as, yeast extract and potassium silicate to overcome the effects of these undesirable conditions.

Squash plants is very sensitive to agroclimatic factors like photoperiod and temperature considerably during critical development stages which influenced on plant growth and yield (Bannayan et al., 2011).In this respect, genotypes behave differed under different environmental conditions and most crop cultivars were adapted to temperature where it is the major factor affected on their distribution (Moursy et al., 2014). Numerous studies on the cultivars of cucurbitaceae members family indicated that flowering characters, yield and its components, as well as fruit physical and chemical parameters have highly variation depending on 
their genetic make -up and/or environmental factors (Marie et al., 2011, Yoldes, 2014, Esho and saeed, 2016 and 2017 Hassan et al., 2016 , Mousa and AlQurashi, 2017 as well as Kumar and Sharma,2018).

Lately, foliar spray of growth stimulants considered as one of the most important points among management strategy to improve growth, flowering, yield and quality of horticultural crops particularly under stress conditions.

Growth stimulants are micro-organisms or substances supplemented for plants to enhancement the tolerance of the abiotic stress, nutrient uptake and efficiency, as well ass crop quality. Both yeast as fungi and silicon as inorganic compound considered amoung these biostimulants (Laane ,2018).

Yeast extract has become a hot topic for used with various plants as it is more natural, safe and low cost. Moreover, it is rich in effective constituents, such as low-molecular-weight organic matter, amino acids, nucleotides, peptides, nitrogen, phosphorus and trace elements (Vieira et al., 2016).

Additionally, yeast extract contains vitamins especially B- Complex vitamins, enzymes and phytohormones such as, auxins and cytokinins (Barnett et al., 1990 and Glick, 1995). The improvement of some vegetable crops attributes by application of yeast extract were recorded by Hamail et al.(2014) and Shehata et al.(2016) on flowering characteristics, Nassef and El-Aref (2016), Shehata et al.(2016) Morsy et al. (2018) and Al-Madhagi (2019) on yield and fruit quality.Also, it had a beneficial role during stress conditions due to the exist of cytokinins in its content (Barnett et al., 1990).

Potassium silicat can be used in agricultural production systems where, it is a good source of highly soluble from each potassium and silicon. Foliar application of silicon has a biostimulative effect, and the best results are observed in stressful conditions for plants such as, salinity, high and low temperature and the strong pressure of diseases and pests (Mitani and Ma, 2005). Also, it is important to underline of the fact that foliar application of silicon is safe for the natural environment and can also be used in organic farming. In this respect AbdAlkarim et al. (2017) on cucumber reported that foliar spray of silicon improving the flowering behavior of plants, yield and fruit quality. As for potassium, it is among the principal elements for plant growth and physiology. It is vital for plant survival under physiological and stress conditions. Potassium helps in energy transport, water and nutrients movement, as well as influencing on many physiological and biochemical processes, such as respiration, photosynthesis, 
carbohydrates metabolism, protein synthesis and enzyme activation (Wang et al., 2013).

In addition, Abduljabbar and Mohammed (2010) and Fekry (2016) on summer squash, as well as , Kazemi (2013) and Shafeek et al. (2013) on cucumber reported that potassium foliar application increased the number of pistillate flowers, as well as yield and fruit quality. Furthermore, many recearchers studied the effect of spraying potassium silicate on different vegetable crops among them Dehghanipoodeh et al. (2016) who found that potassium silicate enhaced flowering in strawberry. El- Bassiony et al. (2010) and Atress and Rashid, (2016) on sweet pepper, Rakha, (2014) and Hussein and Muhammed, (2017) on eggplant and Merwad, (2018) on pea mentioned that foliar spray plants with potassium silicate increased yield and its components, as well as fruit quality.

Therefore, the objective of this study was to investigate the effect of some squash cultivars and spraying yeast extract and potassium silicate on flowering, yield and fruit quality at fall- winter season in open field conditions.

\section{MATERIALS AND METHODS}

This investigation was carried out during the two successive fall-winter seasons of 2015/2016 and 2016/2017 at the Experimental Farm, Faculty of Technology and Development (Ghazala region - Zagazig ), Zagazig University, Sharkia Governorate, to study the influence of different squash cultivars (Cucurbita pepo L.) and foliar application with yeast extract and potassium silicate on flowering behavior, as well as yield and fruit quality under open field conditions.

Soil texture of the experimental field was clayey . Soil chemical analysis was applied using the method described by Black (1982). Results of ${ }_{\mathrm{P}} \mathrm{H} 8.54-$ 8.50, organic matter (g/kg)10.45-10.40 and available $\mathrm{N} \mathrm{22-20,} \mathrm{P22-19} \mathrm{and}$ $\mathrm{K} 323-290$ ( $\mathrm{mg} / \mathrm{kg}$ soil)in the first and second seasons, respectively.

The local meterological data during the two growing seasons was performed by the National Authority for Meterology are shown in Table 1.

This experiment included fifteen treatments which were the combinations between three cultivars of squash, i.e., Eskandarany, Revera and

Azyad and five foliar applications, i.e., control (tap water), yeast extract at rates of 3 and $6 \mathrm{gl}^{-1}$, as well as potassium silicate at the rates of 2 and $4 \mathrm{gl}^{-1}$. 
Table 1. The meterological data during the two growing seasons in Zagazig City Sharkia Governorate, Egypt.

\begin{tabular}{l|cccccc}
\hline \multirow{3}{*}{ Months } & \multicolumn{5}{|c}{ Temperature $\left({ }^{\circ} \mathbf{C}\right)$} \\
\cline { 2 - 7 } & \multicolumn{3}{|c|}{ 2015/2016 season } & \multicolumn{3}{c}{$\mathbf{2 0 1 6} / \mathbf{2 0 1 7}$ season } \\
\cline { 2 - 7 } & Maximum & Minimum & Mean & Maximum & Minimum & Mean \\
\hline October & 32.0 & 19.0 & 22.5 & 31.0 & 17.0 & 24.0 \\
November & 25.0 & 15.0 & 20.0 & 27.0 & 13.0 & 20.0 \\
December & 22.0 & 10.0 & 16.0 & 23.0 & 9.0 & 16.0 \\
January & 18.0 & 9.0 & 12.5 & 19.0 & 9.0 & 14.0 \\
\hline
\end{tabular}

Treatments were arranged in a split plots system in a randomized complete blocks design with four replicates. Cultivars were randomly situated in the main plots and those of foliar applications with yeast extract and potassium silicate were randomly put in the sub-plots.

The source of squash seeds cultivars (Eskandarany, is a local cv., secured from the Agricultural Research Center (ARC), Ministry of Agriculture; Revera, is a hyprid cv.,, produced and manufactured by Seminis Vegetable Seeds Company, USA and Azyad,is hyprid cv., produced by Sakata Vegetables Company, Jaban. As the sources of foliar spray treatments, potassium silicate $\left(\mathrm{K}_{2} \mathrm{SiO}_{3}\right)$ which contain $11 \% \mathrm{Si}$ and $60 \% \mathrm{~K}_{2} \mathrm{O}$, it imported by Technogene Company from China. Yeast extract, was prepared from active dry yeast (Saccharomyces cerevisiae). It was dissolved in water and sugar was added at the ratio $1: 1$, kept in warm place for 10 minutes to activation and reproduction.

Seeds of the tested cultivars were sown in nursery at October $5^{\text {th }}$ in both seasons of 2015/2016 and 2016/2017. Squash seedlings were transplanted to the open field in October $15^{\text {th }}$ and $17^{\text {th }}$ in the first and second seasons, respectively. Each experimental plot area was $11.2 \mathrm{~m}^{2}$, it comprised of four ridges, $4 \mathrm{~m}$ length and $0.7 \mathrm{~m}$ width. Transplants were spaced $45 \mathrm{~cm}$ apart, on one side of the ridge. Foliar spray treatments were applied four times 10, 20, 30 and 40 days after transplanting, respectively.

Ammonium sulphate $(20.5 \% \mathrm{~N})$, calcium superphosphate $(15.5-16.0 \%$ $\left.\mathrm{P}_{2} \mathrm{O}_{5}\right)$ and potassium sulphate $\left(48-50.0 \% \mathrm{~K}_{2} \mathrm{O}\right)$ were used as the sources of $\mathrm{N}$, $\mathrm{P}$ and $\mathrm{K}$ mineral fertilizers at the rate of $200 \mathrm{~kg}, 150 \mathrm{~kg}$ and $100 \mathrm{~kg}$ per feddan, respectively. All the amount of phosphorus fertilizer was applied once during soil preparation. The amounts of nitrogen and potassium fertilizers were added in two equal doses, 20 days after transplanting and during the flowering time. 
All other normal culture practices were done according to the recommendation by the Ministry of Agriculture for squash crop.

\section{Data recorded}

Floral characteristics: At flowering stage (about 30 days from seed sowing), a random sample of three plants from each experimental plot was labeled. Number of both male and female flowers were counted all over the period of flowering. Sex ratio and femaleness percentage were determined according to the following equations which reported by Gad et al.(1993).

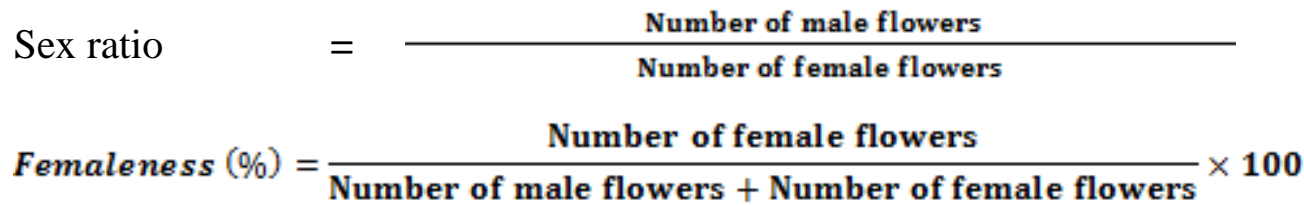

Yield and its components: Squash fruits were harvested twice weekly, number of fruits per plant, fruit fresh weight and dry matter percentage of fruit were determined, as well as total fruit yield per plot and relative yield were calculated.

Fruit quality: It was determined at the mid of harvesting season by using ten fruits from each plot, as follows,

1- Fruit physical characters, such as fruit length and diameter .

2- Fruit chemical constituents, were determined in dry basis by oven dried the samples at $70^{\circ} \mathrm{C}$ till constant weight and then ground. $\mathrm{N}, \mathrm{P}$ and $\mathrm{K}$ content were assayed according to the methods advocated by Horneck and Miller (1998), Cottenie et al. (1982) and Chapman and Pratt (1982), respectively. Protein percentage according to A.O.A.C.(1990),by using the following equation:

$$
\text { Protein }(\%)=\text { Total nitrogen } \times 6.25 \text {. }
$$

Total carbohydrates $(\%)$, was determined according to the method described by Dubois et al.(1956).

\section{Statistical analysis}

Analysis of variance (ANOVA) using SAS Institute program (2008), performed to detect the differences between treatments. Means were compared using L.S.D at 0.05 probability level, as the methods depicted by Gomez and Gomez (1984). 


\section{RESULTS AND DISCUSSION}

\section{Floral characteristics}

\section{a. Effect of cultivars}

Data in Table 2 show that there were a significant differences among the three tested cultivars at all studied floral parameters.

Results indicated also that Azyad $c v$, recorded the highest number of female flowers per plant, and femaleness percentage, whereas sex ratio was the lowest one compared with the two other tested cultivars. Moreover, the hypride Revera cv., appeared the same flowering habit in this concern.

On the contrary, Eskandarany cultivar recorded the lowest number of male and female flowers per plant, femaleness percentage, as well as the highest value of sex ratio. Obtained results hold true in the two growing seasons. In this connection, the increment in number of female flowers of the two hybrid cultivars Azyad and Revera may be attributed to the genetic variations and / or environmental conditions. In this connection, Hume and Lovell (1983), Van Der Vlugt (1983), as well as Mousa and Al- Qurashi (2017) in cucurbits plants indicated that the variation in floral characters depending on environmental factors, i.e., temperature and photoperiod, as well as cultivar. Moreover, Ne Smith and Hoogenboom (1994) and Mady (2014) on squash, as well as Wien (2002) on some cucurbits vegetable crops demonstrated that the number of female flowers increased over male flowers when plants exposed to low temperature during winter season as a result to higher assimilate content of carbohydrates which enhance plants to the femaleness expression.

In addition, Aly (2002) observed the increasing of male and female flowers number, as well as decrease of six ratio in some hybrid squash cultivars compared with Eskandarani cv., during winter season. Moreover, Moursy et al. (2014) concluded that hybrid cultivars Rozina and Revera are suitable to sowing in season or areas had low temperature to start or finish any of phonological stages, particularly flowering stage compared with Eskandarani cv., which able to grow under the opposite conditions. On the other hand, many workers demonstrated that the differences between squash cultivars in floral habit produced by the genetic make -up (Marie et al., 2011, Esho and Saeed, 2016 and Hassan et al., 2016). 


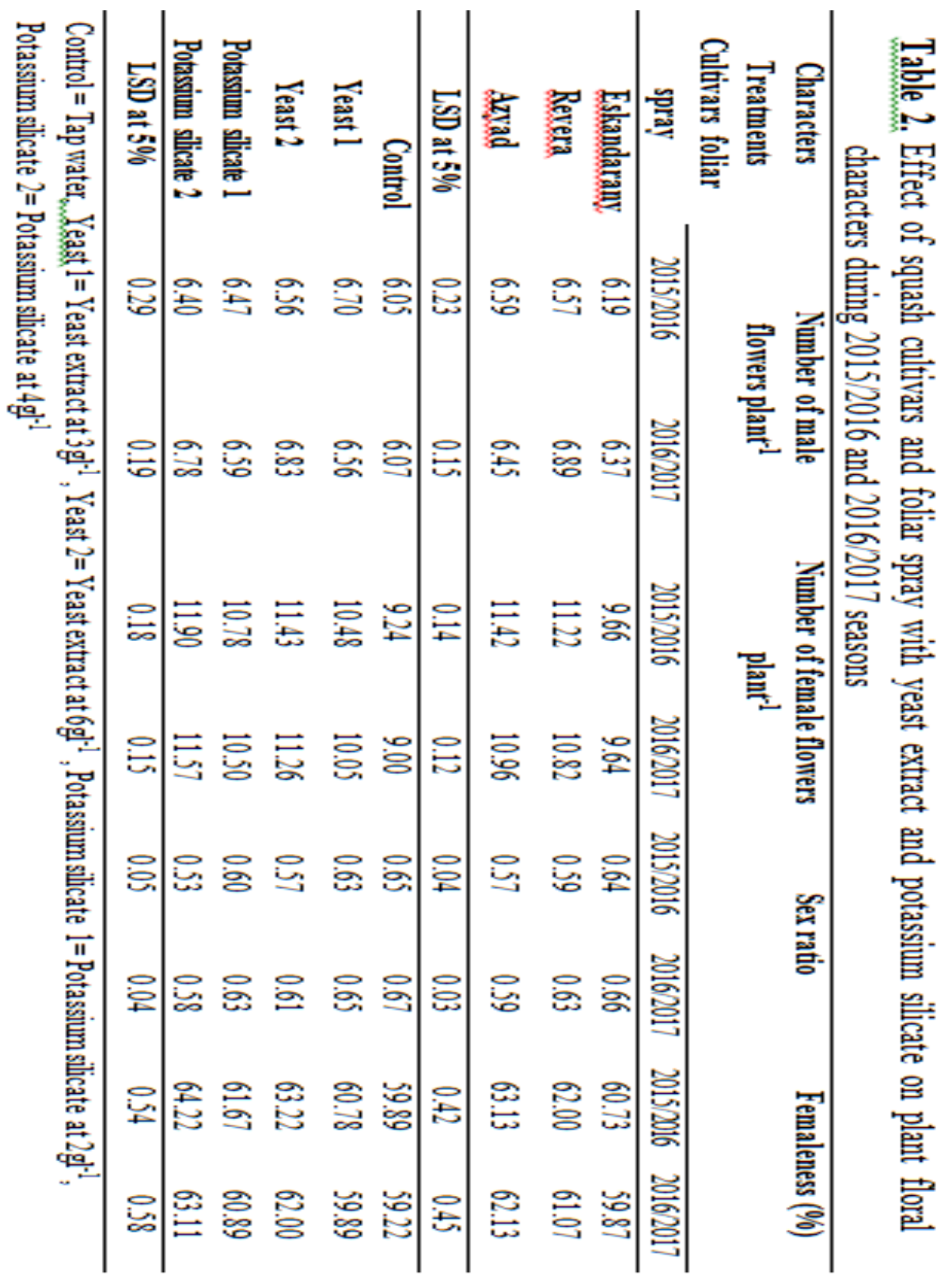




\section{b. Effect of foliar spray with yeast extract and potassium silicate}

Obtained date in Table 2 show that there were a significant differences among the foliar spray treatments in most measured floral characters. It is clear that potassium silicate at the rate $4 \mathrm{gl}^{-1}$ or yeast extract at $6 \mathrm{gl}^{-1}$ exhibited the highest values in the number of female flowers, femaleness and the lowest one of sex ratio compared with the control and other applications. These results were similar in both growing seasons.

In this regard, the promoting effect of potassium silicate on sex expression under winter season conditions, i.e., increasing the number of female flowers and reduce sex ratio, may be attributed to both silicon and potassium involvement in numerous metabolic and physiological processes in plant through enhancing or suppressing the uptake and translocation of some elements depending on the biotic and abiotic conditions, as well as increased carbohydrates translocation and accumulation (Wang et al., 2013 and AbdAlkarim et al.,2017). In this respect Fekry (2016) on squash and Shafeek et al.(2013) on cucumber reported that foliar application of potassium increased the number of pistillate flowers and femaleness, whereas decreased both the number of staminate and sex ratio in these plants. Moreover, Dehghanipoodeh et al. (2016) indicated the enhancing effect of potassium silicate and nanosilica on strawberry flowering.

Furthermore, the advantages of spraying yeast preparation on flowering characters could be due to its contain of essential bioconstituents, i.e., carbohydrates, protein, hormones (GAs, IAA, Cytokinins), minerals content and vitamins particulary B-complex vitamins which affected on physiological and biochemical processes in plants such as ion uptake, cell division and elongation, hormonal and enzymatic activities and this reflected on induces the growth as well as flowering (Barnett et al.,1990 and Vieira et al ., 2016).In addition, Hamail et al. (2014) and Shehata et al. (2016) reported that yeast treatments play a beneficial role in improving the formation of flowers in cucumber plants due to its effect on carbohydrates accumulation.

\section{c. Effect of the interaction between cultivars and foliar spray with yeast extract and potassium silicate}

Data presented in Table 3 show clearly that, the highest values of female flowers number, femaleness and reduction in male / female flowers ratio was showed by the interaction among Azyad $c v$., with $4 \mathrm{gl}^{-1}$ potassium 


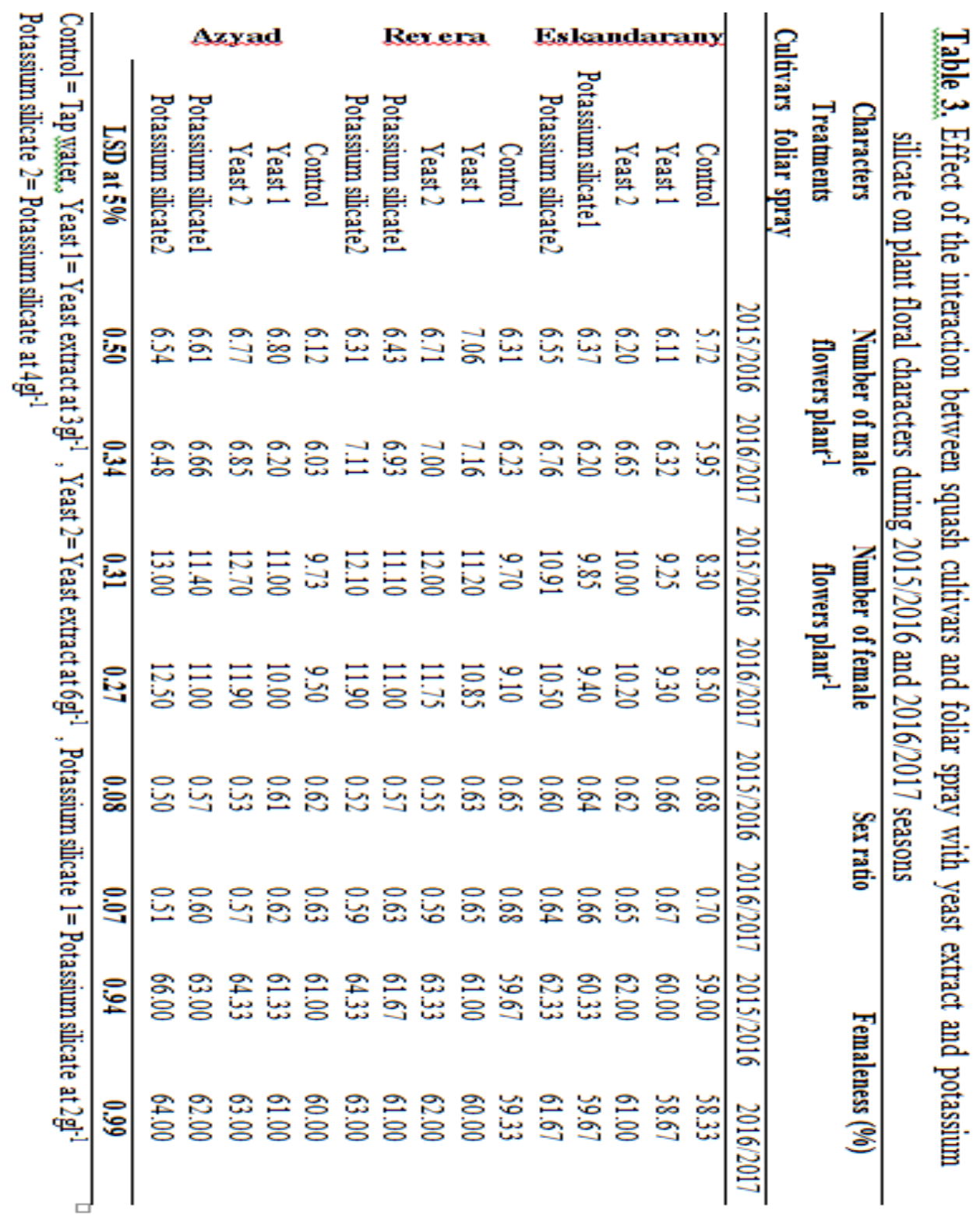


silicate followed by the treatment $6 \mathrm{gl}^{-1}$ yeast extract as foliar application during the two seasons of study.

\section{Yield and its components}

\section{a. Effect of cultivars}

It is clear from such data in Table 4 that most measured yield parameters were significantly differed among the tested cultivars. In this respect, Azyad cultivar recorded the highest fresh weight, dry matter percentage, maximum number of fruits plant ${ }^{-1}$ and yield plot $^{-1}$,followed by Revera cultivar, compared with Eskandarany cv., which achieved the lowest values in these parametars during the two seasons of study.

The increase in total yield per plot were about $28 \%$ and $32 \%$ by Azyad cv., followed by Revera cv., which the increased reach to $20 \%$ and $22 \%$ compared with Eskandarany cultivar in both growing seasons, respectively. The differences in yield and its components between tested varieties may be attributed to the variation in genetic structure, which capable to adapte with the environmental growing conditions, as well as the potential to transport and accumulate photosynthetic assimulate materials, beside the minerals concentration absorbed and uptake by plants. Moreover, the increase in squash hybrid cultivars (Azyad and Revera) might be attributed to the increase of the distillate flowers number as shown in Table 2, which in turn enhanced the number and yield of fruits either per plant or total yield. These results are in accordance with those obtained by Aly (2002), Yoldas (2014) and Hassan et al. (2016) on summer squash, who recorded a significant difference between the tested hybrid squash cultivars and Eskandarany cv., in yield and its components. In this connection, Marie et al.(2011), Esho and Saeed (2016 and 2017), as well as Kumar and Sharma (2018) all working on different varieties and hybrids of squash, and Ene et al. (2016) on cucumber, reported that the differences between either squash or cucumber varieties in number of fruits per plant and total yield attributed to the genetic variation. However, Bielinski et al. (2008) stated that members of cucurbits plants are adapted to particular dominant of temperature which considered a main factor influencing of flowering, the opening of flowers, as well as growth of fruits which reflected on yield. Meanwhile, Moursy et al. (2014) demonstrated that the variability between the evaluated squash varieties in yield and its components may be due to the genetic make - up and environmental factors. 


\begin{tabular}{|c|c|c|c|c|c|c|c|c|c|c|c|c|c|c|}
\hline 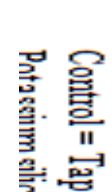 & 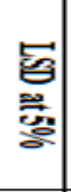 & 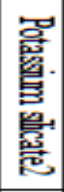 & 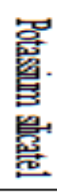 & 茞 & 茞 & 㥶 & 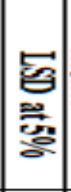 & 嚆 & 造 & 䃾 & & 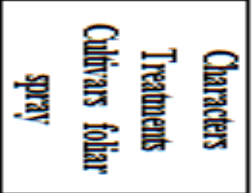 & & 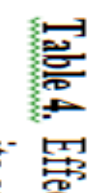 \\
\hline 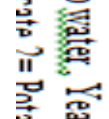 & 至 & 응 & 危 & 옹 & $\stackrel{9}{0}$ & 窈 & 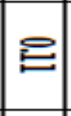 & 遂 & 洛 & $\overrightarrow{\mathrm{Z}}$ & 氨 & 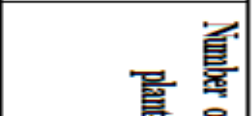 & & 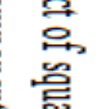 \\
\hline 票 & 용 & 옹 & 용 & 远 & : & $\overrightarrow{\mathrm{s}}$ & 居 & 疍 & $\infty$ & 로 & 袌 & - 宦 & 鹪. & 恕 \\
\hline 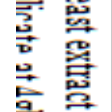 & 总 & 总 & 象 & 恿 & 䍃 & 콩 & 营 & 洛 & 号 & 案 & 莺 & & है & 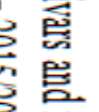 \\
\hline T & $\mathbf{s}$ & $\stackrel{8}{3}$ & $\stackrel{\varrho}{\varrho}$ & : & : & 영 & 总 & 桑 & శ్రి & 总 & 曽 & 噮- & 惢 & 臺 \\
\hline 晜 & 령 & 향 & 㤐 & 总 & : & : & 용 & 参 & 氙 & $\ddot{g}$ & 莺 & 冨 & $\stackrel{0}{0}$ & $\frac{3}{\frac{3}{5}}$ \\
\hline 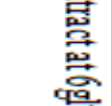 & 용 & 岕 & 㱒 & 㚃 & 必 & $\ddot{8}$ & 잉 & 点 & 5 & 造 & 莺 & 良 & 总 & 㤎 \\
\hline 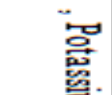 & 民 & 突 & 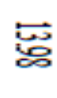 & 志 & $\overrightarrow{0}$ & ᄅ्ర్ర & 욜 & 宽 & : & 言 & 莺 & & & 总 \\
\hline 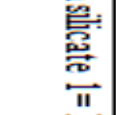 & 잉 & 䓌 & 总 & 壱 & 突 & 产 & 至 & 䓌 & 悹 & 离 & 兽 & 물 & & 点 \\
\hline 窇. & . & 茞 & 焉 & $\overrightarrow{8}$ & $E$ & 8 & ' & : & : & 8 & 莺 & 塄 & & \\
\hline $\begin{array}{l}\text { 总 } \\
\text { 总 } \\
\text { 离 }\end{array}$ & . & 帘 & 已્త & 告 & 롱 & 8 & ' & 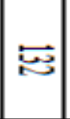 & E & 8 & 总 & 豆- & & \\
\hline
\end{tabular}




\section{b. Effect of foliar spray with yeast extract and potassium silicate}

Results in Table 4 show clearly that different foliar supplied had significant effect on most characters of yield and its components in both seasons. Furthermore, it is worthy to mention that the treatments $4 \mathrm{gl}^{-1}$ potassium silicate followed by $6 \mathrm{gl}^{-1}$ yeast extract as foliar spray excerted a marked and significant effect of all studied parameters expressed as number of fruits per plant, fruit fresh weight and dry matter percentage, as well as total yield per plot and relative yield. The total fruit yield plot $^{-1}$ of squash recorded increase about 46 and $50 \%$ by $4 \mathrm{gl}^{-1}$ potassium silicate over the gained by control treatment(tap water) during the two seasons, respectively

From the above mentioned results, it could be suggested that, the superiority of potassium silicate in this respect may be attributed to the combination effect between the two sources, silicate and potassium which potassium silicate contains. Silicon had profitable effects on plant growth, yield quality, stimulate photosynthesis and improvement the resistance of plant to abiotic and biotic stresses (Mitani and Ma, 2005, Abd- AlKarim et al., 2017 and Laane, 2018). In the same time, the favorable effect of potassium on yield and its attributes might be interpreted to spraying potassium increased the available potassium which needed to accomplish the two processes flowering, as well as fruit setting and consequently reflected on all yield parameters. Potassium had main role in producing more pistillate flowers, enhancing femaleness and decreased sex ratio as shown in Table 2 which in turn on number of fruits, total yield and fruit quality (Abduljabbar and Mohammed 2010 and Fekry, 2016 on squash, and Kazemi, 2013 on cucumber). In this connection, several studies on different vegetable crops came to similar conclusion on the effect of potassium silicate, Atress and Rashid (2016) on sweet pepper, Hussein and Muhammed (2017) on eggplant and Merwad (2018) on pea. They found that foliar spray of potassium silicate increased number of fruits, yield and fruit quality of these plants.

The improvement of yield by spraying yeast extract may be suggested to its beneficial role through improving flower formation particullary female flowers as shown in Table 2. Moreover, this effect may be attributed to its own content of various nutrients, high percentage of proteins, vitamins especially B- complex and levels of endogenous hormones, i.e., IAA and cytokinins (Barnett et al., 1990 and Vieira et al., 2016) . In addition, Hamail et al. (2014) on cucumber concluded that the advantages effect of yeast extract on increased yield could be attributed to 
the increment of leaf area and its influence on photosynthesis, accumulate more carbohydrates hence enhancement femaleness, as well as formed fruits. These results were consistent with the previous findings of Shehata et al. (2012 and 2016), , Nassef and El-Aref (2016) and Al- Madhagi (2019) on cucumber, as well as Morsy et al. (2018) on melon, who found that foliar spray of yeast extract appear to have a positive effect of different cucurbit plants yield.

\section{c. Effect of the interaction between cultivars and foliar spray with yeast extract and potassium silicate}

Data in Table 5 show that, spraying the plants of cvs Azyad and Revera by potassium silicate at $4 \mathrm{gl}^{-1}$ or the application $6 \mathrm{gl}^{-1}$ of yeast extract reflected the highest produced yield and its components in most cases compared with the other interaction treatments during both seasons of study. Furthermore, the relative yield increment in Azyad cultivar reach to 55 and 51\%, as well as 48 and $49 \%$ in Revere cultivar in the first and second seasons, respectively when treated with $4 \mathrm{gl}^{-}$ ${ }^{1}$ potassium silicate over the interaction treatments.

\section{Fruit quality}

\section{Fruit physical characters}

\section{a. Effect of cultivars}

Data in Table 6 reveal that both of the studied characters, i.e., fruit length and diameter were significantly differed among the varieties during the two seasons of study. In this regard, fruits produced by the hybrid cultivars, Azyad and Revera ' respectively show the highest values of the two tested characteristics compared with Eskandarany cv., This increment in these characters of fruits may be refer to the genetic variation between the genotypes. In this regard, Esho and Saeed (2016) and Hassan et al. (2016) indicated that the variability among summer squash varieties attributed to its genetic make-up. The

varietal differences in this connection were also reported by Aly (2002) and Yoldas (2014) who working on summer squash, and Ene et al. (2016) on cucumber. They demonstrated that fruit physical characters were significantly affected by the variety.

\section{b. Effect of foliar spray with yeast extract and potassium silicate}

Data in Table 6 indicate that most the foliar spray applications, i.e., 3 and $6 \mathrm{gl}^{-1}$ of yeast extract or 2 and $4 \mathrm{gl}^{-1}$ of potassium silicate significantly increased the measured squash fruit physical characters compared to the control treatment 


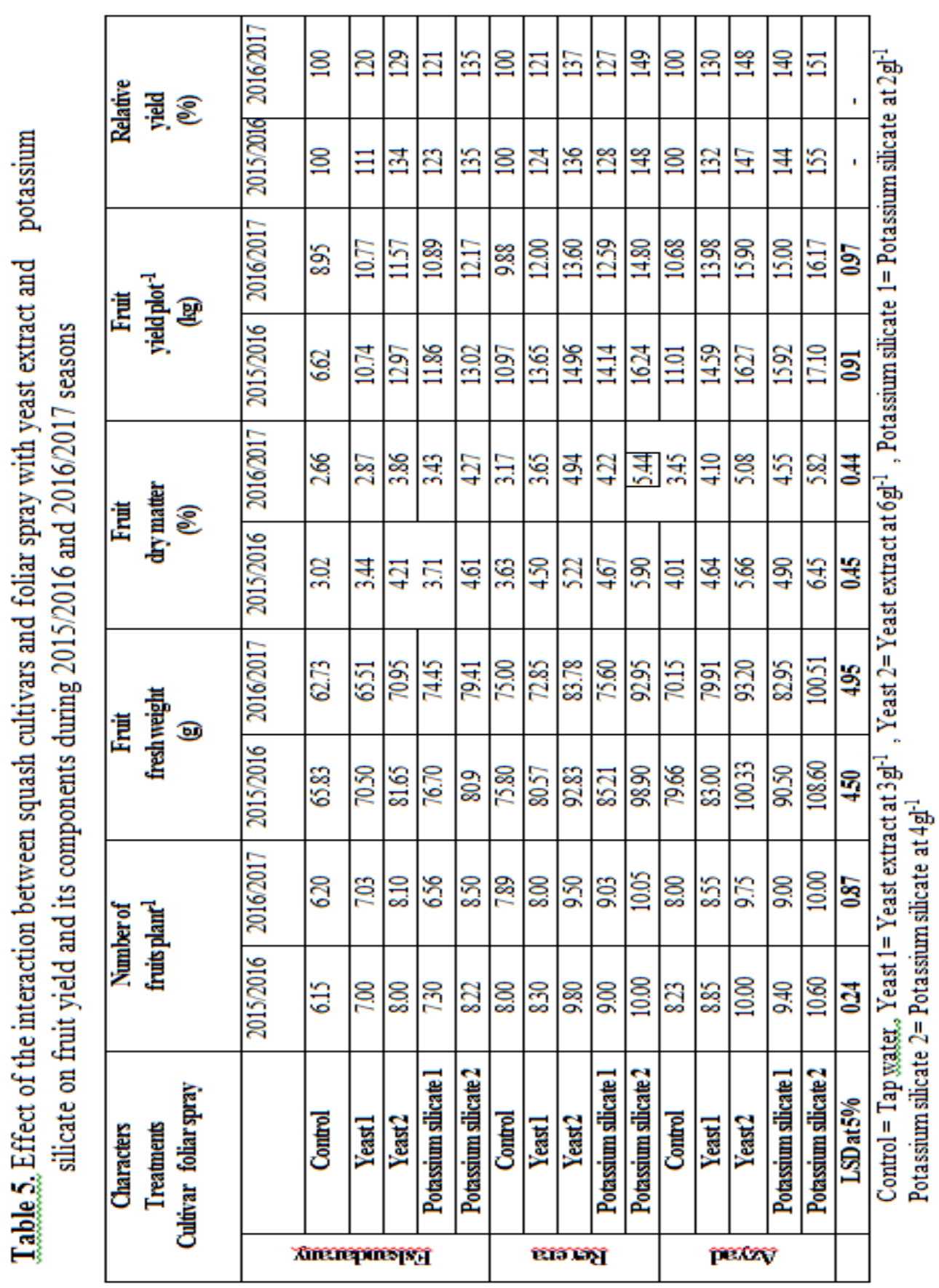




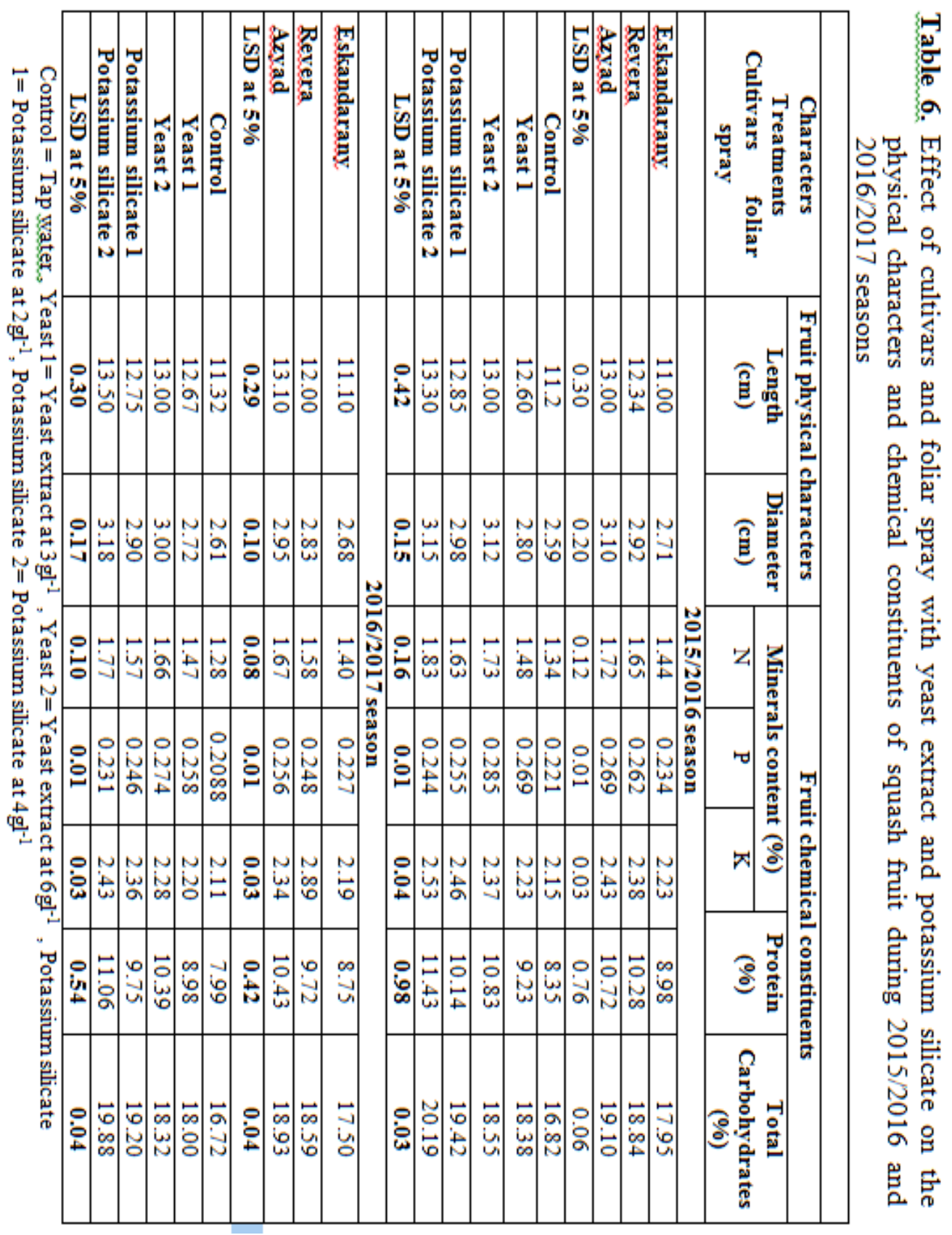


during both seasons of the experiment. Furthermore, using potassium silicate at $4 \mathrm{gl}^{-1}$ followed by yeast extract at $6 \mathrm{gl}^{-1}$ in the second rank exhibited the highest values in this respect. Obtained results are true during the two seasons of growth. Such increments by potassium silicate may be due to the role of both potassium and silicate for faced the biotic and abiotic conditions which adversely affect on the strength and improved growth parameters, as well as physiological process especially photosynthesis which reflected on the quantity of assimilate products and its translocation in fruits. In this respect Ashraf et al. (2010) and Patil et al. (2017) stated that silicon had positively effect on the activities of certain enzymes and reduce the injury caused by abiotic and biotic stress factors and this may reflected on the benefit of crop productivity and quality. Furthermore، Marschner (1995) reported that potassium is participate in several physiological and biochemical processes which in turn affect on vegetative growth yield and its quality, as well as under stress conditions. Similarly، El-Bassiony et al. (2010) on sweet pepper mentioned that fruit quality, i.e., length and diameter were significantly increased by spraying $4 \mathrm{cml}^{-1}$ of potassium oxide.

As for the effect of yeast extract on fruit physical character, it may be due to its high contents of different nutrients, protein, vitamins as well as it considered a rich source of phytohormones particularly cytokinins which enhanced cell division and enlargement (Barnett et al., 1990 and Glick, 1995), which may be promoted plant growth characters and this reflected on quality of yield. Obtained results are in agreement with those of Shehata et al.(2012)and Shehata et al.(2016) on cucumber, as well as Morsy et al. (2018) on melon. They showed that fruit length and diameter were improved by foliar spray of yeast extract.

\section{c. Effect of the interaction between cultivars and foliar spray with yeast extract and potassium silicate treatments}

Data in Tables 7 and 8 revealed that spraying the two cultivars Azyad and Revera with potassium silicate at rate $4 \mathrm{gl}^{-1}$ in the first rank or yeast extract at $6 \mathrm{gl}^{-1}$ in the second rate reflected the highest values of all determined physical fruit traits, i.e., fruit length and diameter compared with other interaction treatments without significant differences in most cases during the two growing seasons of study. 


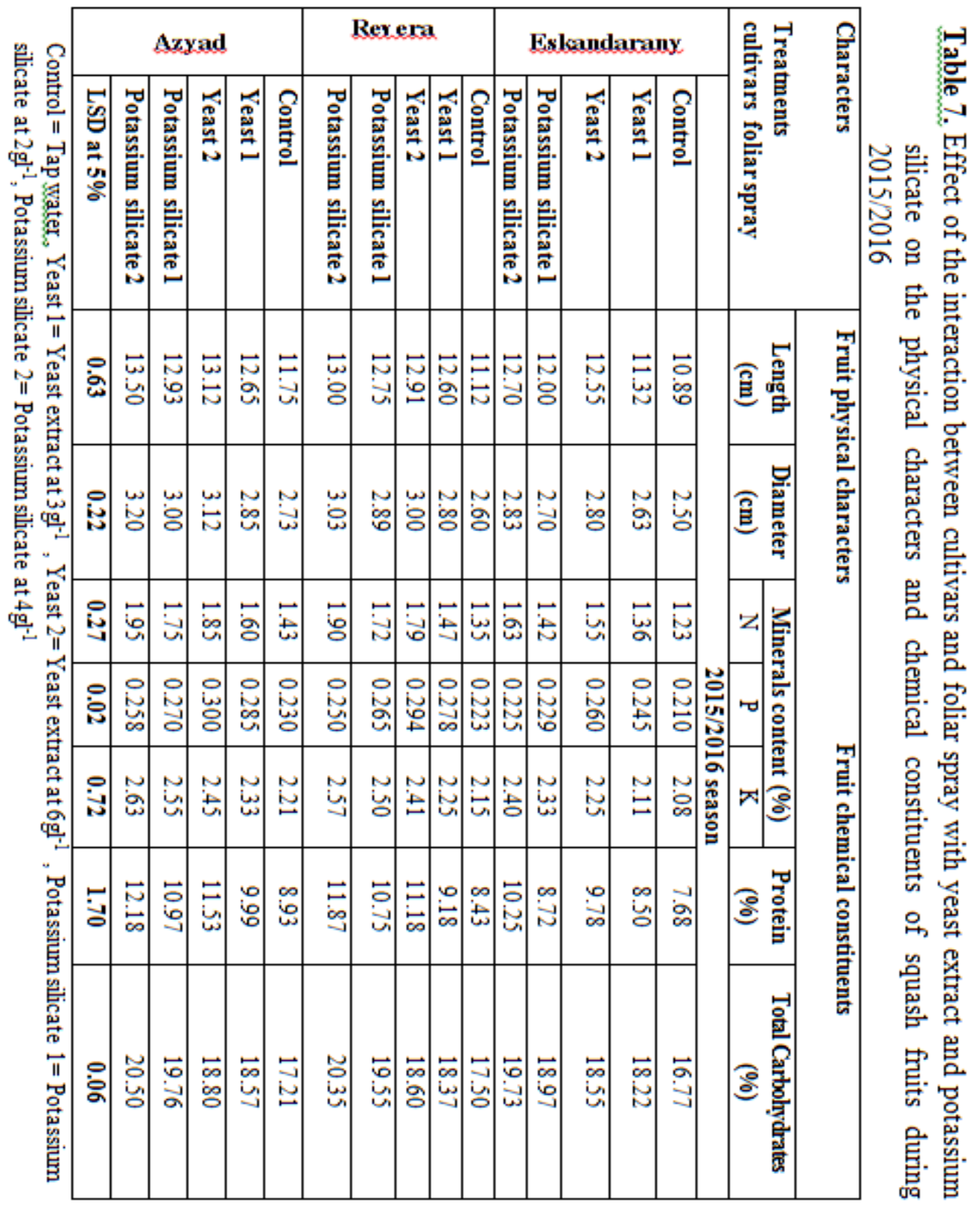




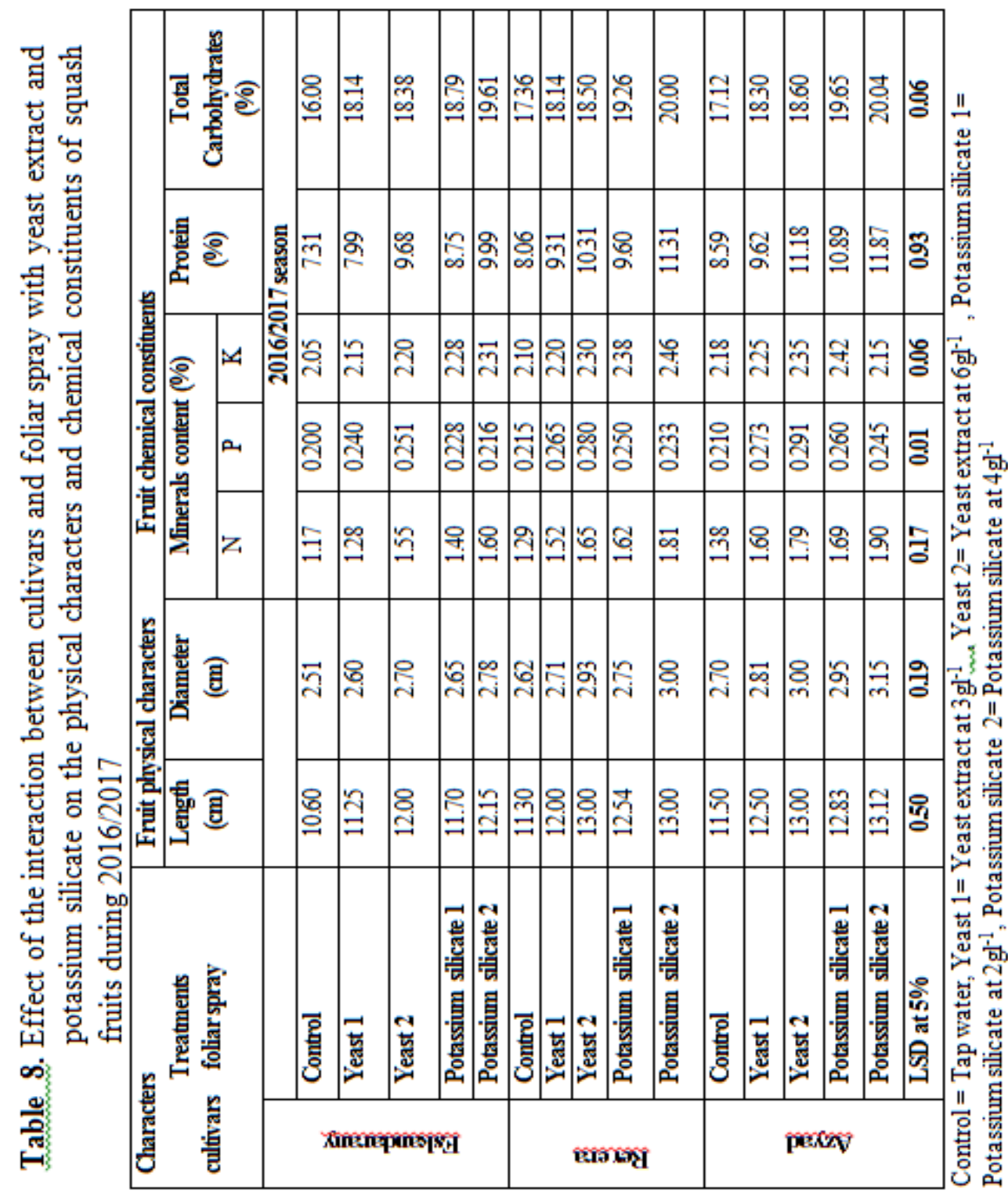




\section{Fruit chemical constituents}

\section{a. Effect of cultivars}

Data presented in Table 6 indicate that, Azyad cv., followed by Revera cultivar exhibited the highest values of all assayed parameters compared with Eskandarany cv., Obtained results are similar during two seasons of study.

In this connection, Rouphael and Colla(2005) found that fruit yield of squash zucchini plants in season summer - fall had the higher fruit quality ' i.e. total carbohydrates ' phosphorus and potassium percentage. Also, Gajc-Wolska et al., (2010) indicated the effect of sowing date on the chemical composition of cucumber fruits. They detected the higher content of nitrogen and phosphorus at autumn season, where potassium percentage were increased at summer cultivation. In addition, Gadomska (2010) found that fixed varieties contained lower total carbohydrates content than heterotic ones.

\section{b. Effect of foliar spray with yeast extract and potassium silicate}

Data in Table 6 indicate that most of the studied chemical composition ,i.e., nitrogen 'phosphorus 'potassium ' protein and total carbohydrates statistically affected by the different applied treatments compared with the control (tap water)

In this respect, such increment in nitrogen content, and protein percentage were recorded in case used foliar spray of potassium silicate at the higher rate $4 \mathrm{gl}^{-1}$ in the first order and yeast extract at $6 \mathrm{gl}^{-1}$ in the second rank. Moreover, the highest values of both potassium and total carbohydrates percentage were obtained by the two used rates of potassium silicate, i.e. 4 and $2 \mathrm{gl}^{-1}$ respectively. On the other hand, foliar spray of yeast extract at the levels 6 and $3 \mathrm{gl}^{-1}$ gave the highest phosphorus percentage in fruit.

The favorable effect of spraying potassium silicate may be attributed to the quickly absorption of its content (potassium and silicate) by plant surface particularly leaves. Both of the two minerals can translocation in plant parts causing improvement of growth, enhancing metabolism and many important regulatory process which due to increase the minerals uptake ، i.e., nitrogen ، phosphorus and 
potassium. (Mohamed et al., 2010 and Marschner, 2012). With regard to the highest values of carbohydrates percentage by foliar spray of potassium ، Mengel (2007), as well as, Lester et al. (2010) reported that potassium considered as one of the essential elements for sugar production, transport, translocation and storage in fruit and decrease of it affected on fruit quality, especially during the critical fruit development period. Furthermore, Kazemi (2013) on cucumber stated that potassium promotes photosynthesis and transport assimilates of the carbohydrates to the storage organs. Moreover, Pal et al. (2016) found that applied plants with potassium increased protein synthesis and accelerating enzymes activity which responsible for biomass accumulation in cucumber fruits . Also ' Abd-Alkarim et al. (2017) on cucumber found that silicon increased fruit chemical composition' i.e., nitrogen ' phosphorus ‘ potassium and protein percentage.

Furthermore, the positive effect of yeast extract on increasing the minerals content, total carbohydrates and dry matter percentage in squash fruits may be attributed to its own content as discussed in floral characteristics as well as fruit yield and its components.

Obtained results are in agreement with those reported by Abdel Nabi et al. (2014) on cantaloupe who found that spraying yeast extract positively affected fruit nitrogen, phosphorus, potassium and total carbohydrates.

\section{c. Effect of the interaction between cultivars and foliar spray with yeast extract and potassium silicate}

Data presented in Tables 7 and 8 show clearly that, the maximum values of minerals concentration (nitrogen, phosphorus and potassium) ' protein and total carbohydrates were obtained as a result of the interaction among Azyad or Revera cultivars with potassium silicate at $4 \mathrm{gl}^{-1}$ followed by the second application $6 \mathrm{gl}^{-1}$ yeast extract as foliar spray compared with other interaction treatments during both seasons of study.

\section{REFERENCES}

A.O.A.C. 1990. Association of Official Analytical Chemists: Official Methods of Analytical, $15^{\text {th }}$ Ed., Washington, D.C. ,USA.

Abd- Alkarim, E., Y. Bayoumi, E. Metwally and M. Rakha. 2017. Silicon supplements affect yield and fruit quality of cucumber (Cucumis sativus L.) grown in net houses. Afr. J. Agric. Res., 12(31): 2518-2523. 
Abdel Nabi, H.M.A, K.K. Dawa, E.I.El-Gamily And Y.F.E.Lmryed 2014. Impact of mineral organic and biofertilization on growth, yield and quality of cantaloupe. J. Plant prod. Mansoura Univ.,5(11):1777-1794.

Abduljabbar, Marie I. and G. H. Mohammed. 2010. Effect of foliar application of potassium and IAA on growth and yield of two cultivars of squash (Cucurbita pepo L.). J. Tikrit Univ. Agric. Eciences, 10(2): 229-241.

Al - Madhagi, I. A. H. 2019. Effect of humic acid and yeast on yield of greenhouse cucumber. J. Hort. Post. Res., 2(1): 67-82.

Aly, Seham M. M. 2002. Effect of some agriculture treatments on yield productivity of squash. Ph. D. Thesis, Fac. Agric. Moshtohor, Zagazig Univ., Benha Branch, 101pp.

Ashraf, M., M. Afzal, R. Ahmed , M.A. Maqsood, Sher M. Shahzad, Ahsan A. and N. Akhtar. 2010. Plant stress. 4 (special Issue 2): 104114. Global Science Books.

Atress, Amal S.H. and I. A.S. Rashid. 2016. Influence of pre-harvest potassium and silicon foliar application on quality and storability of sweet pepper. Egypt. J. Agric. Res., 94 (4): 843-585.

Bannayan, M., E.E. Rezaei and A. Alizadeh. 2011. Climatic suitability of growing summer squash (Cucurbita pepo L.) as a medicinal plant in Iran. Notulae Sci. Biol., 3 (2): 39-46.

Barnett, J. A., R.W. Payne and D. Yarrow. 1990. Yeasts. Characteristics and identification. Cambridge Univ. Press. UK, pp.999.

Bielinski, M. S., C. E. Esmel, S. Slamova and E.A. Golden. 2008. Optimum planting dates for intercropping cucumber, squash and muskmelon with strawberry. Hortechnology, 18(4):656-659.

Black, C.A.1982. Methods of Soil Analysis. Part2. American Society of Agronomy, INC, Pub., Madison, Wisconsin,USA.

Bose, T.K., J. Kabir , P. Dar and P.P. Joy. 2000. Tropical Horticalture, Vol. - 1 Naya Prakash, Calcutta, pp. 145.

Chapman, H.D. and P.F.Pratt. 1982. Determination of minerals by titration method. In: Methods of Analysis for Soils, Plants and Water. $2^{\text {nd }}$ ed., pp. 169-170 Agriculture Division, California Univ., USA.

Cottenie, A., M. Verloo, L.Kickens, G.Velghe and R. Camerlynck. 1982. Chemical analysis of plants and soils. Laboratory of analytical and agrochemistry. State University, Ghent Belgium, p. 63. 
Dehghanipoodeh, S., C. Ghobadi, B. Baninasab, M. Gheysari and S.S. Bidabadi. 2016. Effects of potassium silicate and nanosilica on quantitative and qualitative characterisics of a commercial strawberry (Fregaria ananassa cv., Camarosa). J. Plant Nutr., 39:502-507.

Dubois,M.,K.A.Gilles,J.K. Hamilton, P.A. Rebers and F. Smith. 1956. Colorimetric methods for determination of sugars and related substances. Annal. Chem. Soc., 46:1662-1669.

El-Bassiony, A. M., Z.F. Fawzy, E.H. Abd El-Samad and G.S.Riad. 2010. Growth, yield and fruit quality of sweet pepper plants (Capsicum annuиm L.) as affected by potassium fertilization. J. Amer. Sci., 6(12) : 722-729.

Ene, C. O., P. E. Ogbonna, C. U. Agbo and U. P. Chukwudi. 2016. Studies of phenotypic and genotypic variation in sixteen cucumber genotypes. Chilean J. Agric. Res., 76(3): 307-313.

Esho, K. B. and S. H. Saeed . 2017. Effect of humic acid on growth and yield of three cultivars of summer squash (Cucurbira pepo L.). Egypt. J. Exp. Biol. (Bot.), 13(2) : 167-171.

Esho,K.B. and S.H. Saeed.2016. Correlation and genetic parameters in summer squash (Cucurbita pepo L.). J. Dynamics Agric. Res. , 3 (3): 41-45.

Ferkry, Wafaa A. 2016. Improving squash (Cucurbita pepo L.) plant growth, sex expression and yield by foliar application of potassium and ethephon under high summer temperature conditions. J. Product. \& Dev., 21(3): 383-403.

Gad, A.A., A.A. Alsadon and H.M.wahdan.1993. Sex expression and yield responses of summer squash to ethrel. Ann. Agric. Sci., Ain Shams Univ.,38 (1):251-259.

Gadomska, J. M. 2010. The chemical composition of fruit in selected melon cultivars grown under flat covers with soil mulching. Acta Sci. Pol. Hortorum Cultus, 4(2): 39-52.

Gajc- Wolska, J., K. Kowalczyk and D. Bujalski. 2010. The effect of cultivation term, substrate and cultivar on chemical composition of cucumber fruit (Cucumis sativus L.) in greenhouse production. Acta Hortic., 877: 239-244.

Glick, B. R. 1995. The enhancement of plant growth by free living bacteria. $J$. Microbio., 41: 109-117. 
Gomez, K. A. and A.A. Gomez. 1984. Statistical Procedures for Agricultural Research, $2^{\text {nd }}$ Ed. John Wiely \& Sons, New York, pp.680 .

Gorecki, R.S. and W. D. Busch.2009. Effect of silicate fertilizers on yielding of greenhouse cucumber (cucumis sativus L.) in container cultivation. $J$. Elementol, 14(1):71-78

Gray, S. B., S. M. Brady. 2016. Plant developmental responses to climate change. Developmental Bio. , 419: 64-77.

Hamail, A. F., M. S.Hamada, E. A.Tartoura, and M. A. Abd El-Hady. 2014. Effect of $\mathrm{N}$-forms and bio-stimulants on productivity of cucumber: 2-Flowering characters, yield and its components. J. Plant Prod. Mansoura Univ., 5(4): 573-583.

Hassan, A.A., K.E.A Abdel-Ati and M.I.A.Mohamed.2016. Squash germplasm evaluation for some vegetative growth, flowering and yield characters. Middle East J. Agric. Res., 5 (1):109-116.

Horneck,D.A. and R .O.Miller.1998. Determination of total nitrogen in plant tissue. In hand book of reference Methods for Plant Analysis, ed. Kolra,Y.P., p.73

Hume, R. J. and P. H. Lovell .1983. The control of sex expression in cucurbits by ethephon. Ann. Bot., 52: 689-695.

Hussein, Wafaa A. and M.M. Muhammed. 2017. The response of white eggplant plants to foliar application with boron and potassium silicate. Assiut J. Agric. Sci., 48(1-1): 394-401.

Kazemi, M. 2013. Effect of foliar application of humic acid and potassium nitrate on cucumber growth. Bull. Environ., Pharmacol. life Sci., 2 (11): 3-6.

Kumar, D.and R. Sharma.2018. Effect of mulching on growth, yield and quality in different varieties of summer squash (Cucurbita pepo L.) Int.J. Curr. Microbiol. App.Sci., 7(6):2113-2119.

Laane, H. M. 2018. The effects of foliar sprays with different silicon compounds. Plants, 7(2):45.

Lester, G.E., J.L. Jifon and D. J. Makus. 2010. Impact of potassium nutrition on food quality of fruits and vegetables: A condensed and concise review of the literature. Better Crops, 94(1): 18-21.

Mady, M.A. 2014. Inducing cold tolerability in squash (Cucurbita pepo L.) plant by using salicylic acid and chelated calcium application. Int. J. Agric. Sci. Res., 4(4): 9-24. 
Marie,A.K. ,M.Y.Moualla And M.G.Boras.2011.Study of the most important morphological and productivity chracters of the inbreed lines of squash (Cucurbita pepo L.). Demask Univ. Agric. Sci. J., 27(1) : 337350

Marschner, H. 2012. Marschner's Mineral Nutrition Of Higher Plants, $3^{\text {rd }}$ ed, Academic Press, London, UK., pp:178-189.

Marschner, H. 1995. Functions of mineral nutrients : micronutrients. In : Mineral Nutrition of Higher Plants . $2^{\text {nd }}$ Ed., Academic press, London, pp. 313-404.

Mengel, K. 2007. Potassium: In Handbook of Plant Nutrition, Barker, A.V., Pilbeam, D.J., Eds., CRC Press : Boca Raton, FL, USA, pp. 91-120.

Merwad, A. R. M. A. 2018. Response of yield and nutrients uptake of pea plants to silicate under sand soil conditions. J. Comm. Soil Sci. and Plant Analysis, 49 :1553-1562.

Mitani, N. and J. F. Ma. 2005. Uptake system of silicon in different plant species . J. Exp. Bot., 56 (414): 1255-1261.

Mohamed, Hoda A., Asmaa R. Mahmoud, M. I. Ezzo and Magda M. Hafez. 2010. Physiological response of growth, yield and its quality of squash (Cucurbita pepo L.) to foliar application of some nutrients. Res. J. Agric. Biol. Sci., 4(4) : 568-576.

Morsy, Nahla M., M. A. Abdel- Salam and A. S. Shams. 2018. Comparing response of melon (Cucumis melo L) to foliar spray of some different growth stimulants under two nitrogen fertilizer forms. Egypt. J. Hort., 45(1): 81-91.

Moursy, Fatma S. I. I. Sadek, M. A. M. Heggi and A.A. Farag. 2014. Comparing four different squash hybrids on growing degree days (GDD) bases. Researcher, 6(7):97-111.

Mousa, M. A.A. and A. D. A. Al-Qurashi.2017. Sex ratio, growth and yield of squash (Cucubita pepo L.) cultivars under stresses of different light regimes. Int. J. Biosci., 10 (2) : 49-60.

Nassef, Dalia. M.T. and H. M. El-Aref.2016. Response of cucumber to yeast and royal jelly foliar applications.Assiut J. Agric. Sci., 47(62):633-648.

Ne Smith, D. S. and G. Hoogenboom.1994. Variation in the onset of flowering of summer squash as a function of days and heat units. $J$. Amer. Soc. Hort.Sci., 119(2): 249-252. 
Pal, P., K.Yadav, K. Kumar and N. Singh.2016. Effect of Gibberellic acid and potassium foliar sprays on productivity and physiological and biochemical parameters of parthenocarpic cucumber cv.,,seven star F1'. J. Hort. Sci., 24(1): 93-100..

Patil, Harish, R. V. Tank and P. Manoli. 2017. Significance of silicon in fruit crops. A Review. Plant Archives, 17 (2): 769-774.

Rouphael, Y. and G. Colla. 2005. Growth, yield, fruit quality and nutrient uptake of hydroponically cultivated zucchini squash as affected by irrigation systems and growing seasons. Scientia Hort., 105:177-195.

SAS Institute .2008. SAS User Guides Version 9.2 SAS Institute Inc. Cary. North Carolina, USA.

Shafeek, M.R., Y. I. Helmy, W.A. El-Tohamy and H.M. EL-Abagy. 2013. Changes in growth, yield and fruit quality of cucumber (Cucumis sativus L.) in response to foliar application of calcium and potassium nitrate under plastic house conditions. Res. J. Agric. Biolo. Sci., 9 (3): 114-118.

Shehata, S. A., H. A. Hassan, A. A. Tawfik and Mervat F. Farag. 2016. Improving the productivity and quality of the cucumber crop grown under greenhouse conditions using some stimulants and spraying amino acids. J. Plants Prod. Mansoura Univ., 7(4): 385-392.

Shehata, S. A., Z. F. Fawzy and H. R. El-Ramady .2012. Response of cucumber plants to foliar application of chitosan and yeast under greenhouse conditions. Aust. J. Basic Appl. Sci., 6(4): 63-71.

Van Der Vlugt, J. L.F. 1983. The effect of temperature on formation and abortion of flower buds in gynoecious cucumber plants. Scientia Hort., 20: 323-328.

Vieira, E. F., J. Carvalho, E. Pinto, S. Cunha, A. Almeida and I. Ferreira. 2016. Nutritive value, antioxidant activity and phenolic compounds profile of brewer's spent yeast extract. J. Food compos. Anal., 52: 44-51.

Wang, M., Q. Zheng and S. Guo.2013. The critical role of potassium in plant stress response. Int. J. Mol. Sci., 14:7370-7390.

Wien, H.C. 2002. The Cucurbits: Cucumber, Melon, Squash And Pumpkin. pp.345-386. In: H.C. Wien (ed). The Physiology of Vegetable Crops. CABI, New York.

Yoldas, F. 2014. Effect of plant variety and growing methods on yield and quality in summer squash. Fifth International Scientific Agricultural symposium, Agrosym. P: 358-363. 


\title{
تاثير بعض اصناف الكوسة ومنشطات النمو على الإزهار، والمحصول

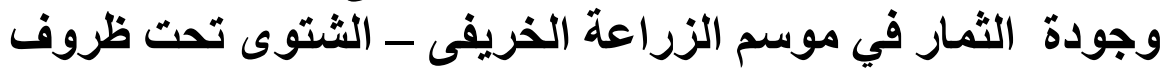

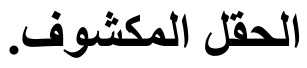

\author{
أحمد رشاد - وفاء عادل فكرى - حلمى وهدان

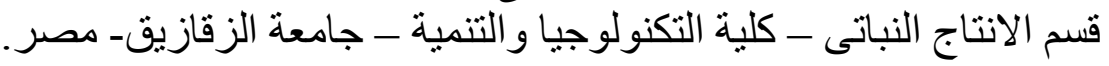

أجريـت هذه الدر اسـة بمزر عـة التجـارب بكليـة التكنولوجيـا والتتميـة (غز الـة ــ الزقازيق)

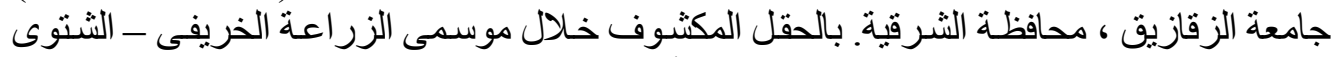

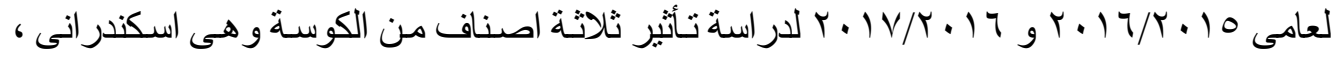

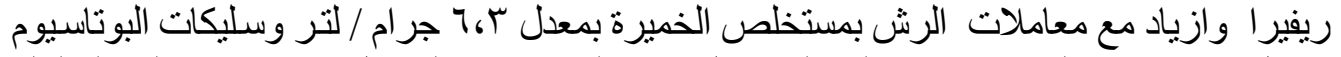

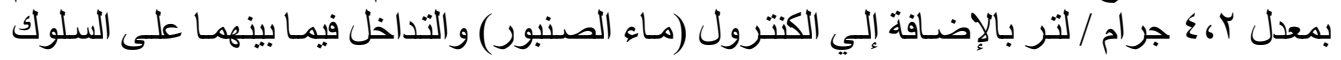

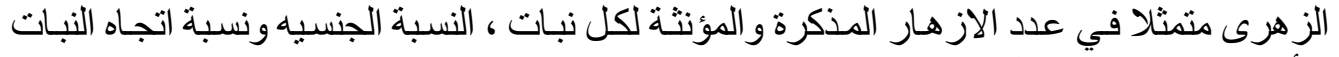

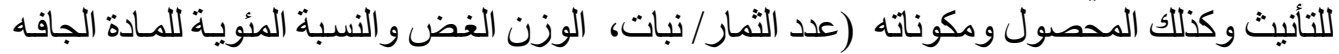

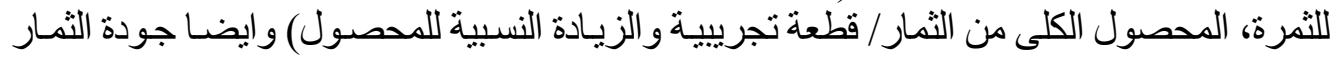

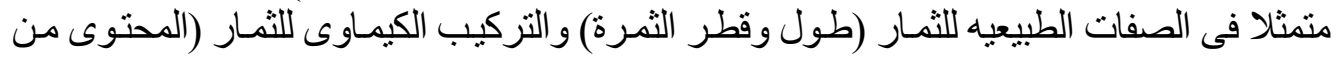

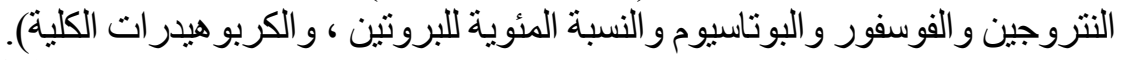

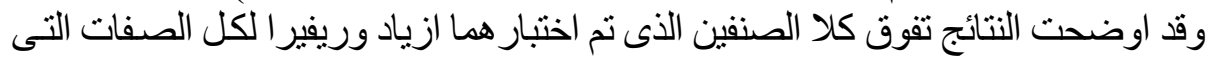

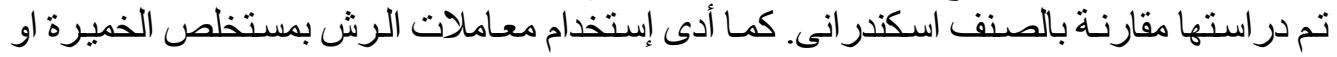

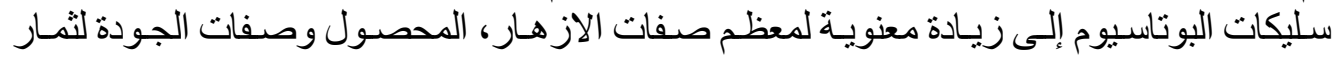

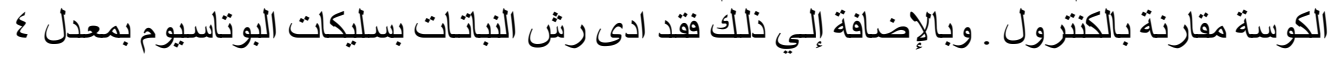

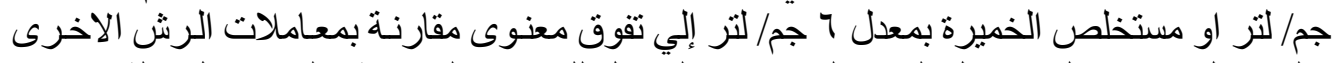

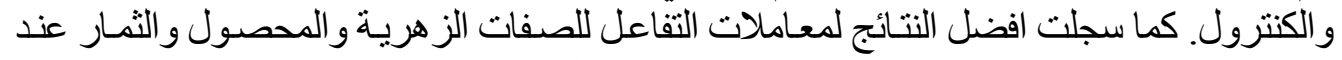
زر اعة اى من الصنفين ازياد او ريفير ا مـع الرش بمعدل ؛ جم/ لتر من سليكات البوتاسيوم او 7

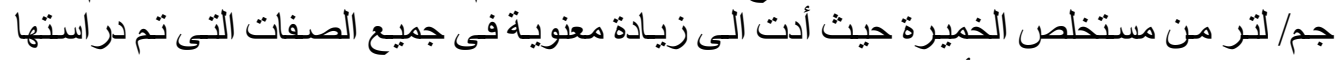

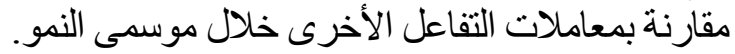

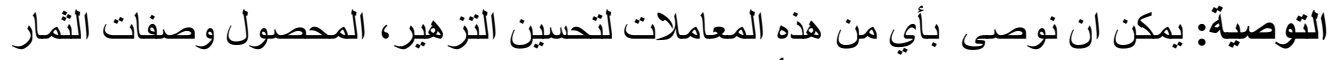

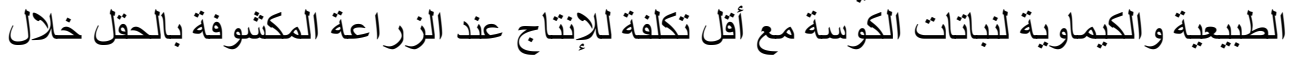

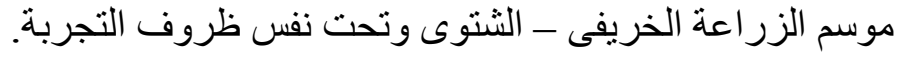

